\title{
THE GROWING CONCEPT OF SOCIAL ENTERPRISE IN AUSTRALIA
}

\section{Can a social enterprise take advantage of tax concessions by operating through a charity?}

\section{Fiona Martin}

\section{Introduction}

Social enterprise is a broad term beneath which sit entities ranging from for-profit businesses that, for example, use only ethically sourced suppliers, to, in some cases, not-for-profits (NFPs) and charities that carry on businesses that support their underlying charitable purposes (Nehme and Martin, 2019). The importance of the latter entities is seen by many researchers as rapidly increasing in western democracies. The report 'Global Civil Society: An Overview' (Salamon, Sokolowski, and List, 2003) found that the number and variety of NFPs or charitable institutions had grown enormously in the 1990s, and there is nothing to suggest that this growth is not still occurring. Expansion of this sector is more marked in developed nations, but it is also occurring in the developing world. These organisations occupy a unique space within the community in that they are private in nature; however, they exist for a public or community purpose (Salamon, Sokolowski and List, 2003). Furthermore, most developed nations offer a variety of tax concessions for charities and NFPs, the most common being the exemption from income tax. For example, the income of charities in England, ${ }^{1}$ the United States, ${ }^{2}$ Hong Kong, ${ }^{3} \mathrm{New}$ Zealand, ${ }^{4}$ and Australia ${ }^{5}$ is generally exempt from income tax. Although not all social enterprises are NFPs, many are (Social Traders, 2016), and all charities must be. ${ }^{6}$

There is no legal definition of NFP in Australia; however, the Australian Taxation Office (ATO) advises that a non-profit (or NFP) ${ }^{7}$ organisation does not operate for the profit or gain (direct or indirect) of individual members both while operating and winding up. Any profit made must be used to carry out the organisation's purposes (Dal Pont, 2000, pp. 22-25). The ATO accepts an organisation as an NFP where its constituent or governing documents prevent it from distributing profits or assets for the benefit of particular people (Australian Taxation Office, 2007, p. 6).

In 'Global Civil Society: An Overview', the researchers found that in the late 1990s, the NFP sector had aggregate expenditures of US $\$ 1.3$ trillion. This represented 5.1 per cent of the combined gross domestic product (GDP) of the 35 countries examined. If this figure is looked at in terms of national economies, it would make it the seventh-largest world economy at that 
time behind the United States, Japan, China, Germany, the United Kingdom, and France and ahead of Italy, Brazil, Russia, Spain, Canada, and Australia (Salamon, Sokolowski and List, 2003). There are currently over 57,000 charities in Australia (Australian Charities and NFO Commission, 2017), and they employ 1.26 million staff (Australian Charities and NFO Commission, 2017). In June 2018, there were 12.6 million people employed in Australia, which means that employees of charities make up almost 10 per cent of all employees in Australia. Charities in Australia, the United States, and other developed nations are major providers of welfare, education, and health services (Powell et al., 2017; Boris, 2012).

As well as seeing the number of charitable entities increase, the number of NFPs in Australia increased from 520,000 in 1996 to 700,000 in 2008 (ATO, 2008-09, p. 61). In Australia, this sector is therefore of growing significance both economically and socially. But not only is there a growth in NFPs and charities, the number and type of what are termed social enterprises are also growing. A 2016 Australian report estimates that there are 20,000 social enterprises in Australia (Social Traders, 2016, p. 9), and 68 per cent of these are in the services sector, of which 24 per cent are in retail and 23 per cent in healthcare (Social Traders, 2016, p. 9).

There are many reasons for the growth of NFPs and social enterprises, including the withdrawal of government from areas which it traditionally dominated, such as disability services, education, and health; the increasing complexity of today's society; and awareness of international issues such as the environment (Koele, 2007, p. 1). The business sector has been criticised for ignoring human needs and producing untenable social inequities (Salamon, Sokolowski and List, 2003, pp. 1-2). The issues with both government and business are considered to foster the growth of the third sector and social enterprises.

This chapter seeks to analyse the overlap, advantages, and disadvantages between social enterprises and charities. It has commenced with an introduction that describes the parameters and impact of the third sector. Part II considers the term 'social enterprise' and reviews the literature around this concept. Part III establishes the legal definition of charity, whether charities can carry on businesses, and the advantages and disadvantages of carrying on a business through a charity. Part IV uses three case studies to illustrate this last point, and Part V is the conclusion.

\section{What is a social enterprise?}

Most social enterprises see themselves primarily as businesses in that they emphasise the importance of trading to build long-term sustainability. In that sense, they are part of the market economy in that they earn revenue from the production and sale of goods and services. However, while traditional businesses trade for the purpose of creating profit, social enterprises operate for a social purpose - profit (or surplus) is only a means to that end. These entities also see themselves as distinct from charities, which have traditionally relied on donations and grants for their operations. However, as charities become more commercial and entrepreneurial, and government grants decrease, many now consider themselves part of the social enterprise sector. This point is discussed in more detail later in this chapter.

Social enterprise is also seen from different perspectives by the stakeholder groups involved in their development and operation. For example, users and consumers of their goods and services value the fact that meeting investor needs is not the main priority of the business model and that they aim to re-invest profits in the social mission of the enterprise. Social enterprises are also gaining recognition because of the developing focus on ethical business practices in the broad community (Reiser and Dean, 2017, pp. 9-10). Many social entrepreneurs and philanthropists see social enterprises as a new way of doing good outside the constraints of charitable status. Governments see social enterprise as a new way of tackling wicked problems, building 
social capital, creating community wealth, and outsourcing public services. Community groups and staff of the enterprises see social enterprise as a new way of becoming involved in the governance of business enterprises. Indeed, ownership and control are essential questions in social enterprise, and ideally the social enterprise should be owned and controlled in the interest of its social or environmental mission. This also means that it may not be an NFP, as some of its profits or capital on a winding up may go back to the original investors.

\section{Review of literature surrounding social enterprise}

As there is no legal definition of social enterprise in Australia, it is not surprising that many practitioners and researchers in this area rely on the 2010 'Finding Australia's Social Enterprise Sector' Report (FASES Report), which is also used in the subsequent 2016 FASES report (Barraket, Mason and Blain, 2016, p. 3). The Report states that social enterprises are organisations that are led by an economic, social, cultural, or environmental mission consistent with a public or community benefit; trade to fulfil their mission; derive a substantial portion of their income from trade; and reinvest the majority of their profit/surplus in the fulfilment of their mission (Barraket et al., 2010, p. 16).

This definition is cited by the Australian Law Reform Commission in their 2019 report 'The Future of Law Reform' (Australian Law Reform Commission, 2019, p. 48). It is also cited by the Australian Institute of Company Directors (Australian Institute of Company Directors, 2015 , p. 1). It is 'the definition utilised in the most substantial public policy investments to date' (Barraket et al., 2017, p. 345, 347).

A slightly different view was taken by a group of researchers and academics who came together through the University of New South Wales, Centre for Social Impact. This group, known as the Legal Models Working Group (Rodgers et al., 2015, p. 8), stated in its 2015 report that the defining features of social enterprise are contained in three essential elements. These are first, trading for social purposes; second, achieving financial sustainability; and third, re-investing profit into the social mission of the enterprise (Rodgers et al., 2015, p. 2).

The authors include 'financial sustainability' as a feature of social enterprises (a feature which is not explicitly stated in the FASES definition), because they consider successful trading and profitability a 'necessary factor for success' of these enterprises. The Report states that '[s] uccessful trading is a necessary factor for success as a SE and an enterprise's social mission can be achieved only if the enterprise continues to be a viable, profit-making, business venture' (Rodgers et al., 2015, p. 13).

The Legal Models Working Group relied for its definition of a social enterprise on the characteristics provided by Social Enterprise, United Kingdom. According to this organisation, social enterprises should (Social Enterprise, 2012, p. 1)

- Have a clear social and/or environmental mission set out in their governing documents;

- Generate the majority of their income through trade;

- Reinvest the majority of their profits;

- Be autonomous of the state;

- Be majority controlled in the interests of the social mission; and

- Be accountable and transparent.

These characteristics make social enterprises clearly different from ordinary businesses, but they also differ from charities and many not-for-profits. The fundamental difference is that not all charities and NFPs generate most of their income through trade. 
The Social Innovation Entrepreneurship and Enterprise Alliance (SIEEA) has been disbanded but described itself as a strategic partnership of intermediary organisations working to support the growth and improve the impact of the 'social economy' in Australia (Pro Bono Australia, 2014). The SIEE Alliance's 2014 report outlined six characteristics of social enterprises. These were:

- Driven by an economic, social, cultural, or environmental mission for public benefit;

- $\quad$ Place people at the centre of their business;

- Trade profitably to fulfil their mission;

- Reinvest profits/surplus in the fulfilment of their mission;

- Engage a wide group of stakeholders in governance and decision-making; and

- Operate with transparency (Social Innovation, Entrepreneurship and Enterprise Alliance, 2014).

Although the core principles are the same, the last two points are interesting additions to the criteria of social enterprises which are not included in the FASES definition.

Social Traders is an organisation which 'connects social enterprises with social procurement opportunities' by certifying social enterprises and facilitating procurement contracts (mostly for government projects/policy) for social enterprises in Australia (Social Traders, 2019a). They are partially funded by the Victorian state government. They have three criteria for social enterprises. First, that they have a defined primary social purpose, environmental, or other public benefit; second, they derive a substantial portion of income from trade; and third, they reinvest 50 per cent or more of their annual profits towards achieving the social purpose (Social Traders, 2019b).

Victoria has a 'strong concentration of social enterprises' which 'may reflect the effects of more consistent public policy support for social enterprise in this state' (Barraket, Mason and Blain, 2016, p. 13). The Victorian government defines social enterprises as organisations that are driven by a public or community cause, be it social, environmental, cultural, or economic; derive most of their income from trade, not donations or grants; and use at least 50 per cent of their profits to work towards their social mission (State Government of Victoria, 2019).

The Australian Institute of Company Directors views social enterprises through the lens of the type of activities that they perform and the audience that they benefit (Australian Institute of Company Directors, 2015, pp. 1-2). They consider that social enterprises can be one of eight types of entities. First are intermediate labour market companies. These are for-profit commercial businesses developed as a method of training and providing work for the unemployed. Second are social firms; these are commercial businesses developed to provide employment for people with a disability. Again, they are for-profit entities. Third are Australian disability enterprises, an Australian government term for businesses developed to employ people with a disability who are unable to work in mainstream organisations; these are also for-profit entities. The final group of five are entities that are more community led and focused. They tend to be NFPs. These comprise cooperatives, associations, and mutual, as in member-run, memberbenefiting businesses which are designed to meet a specific need of members (for example, childcare); community enterprises which are businesses designed purely to benefit the local community (for example, a credit union or petrol station); community development finance institutions, which are businesses created to provide access to financial products for people who find it difficult to access mainstream financial services; fair trade organisations, businesses created to improve the conditions and pay for producers of goods, usually in developing countries, 
through selling accredited goods to developed world consumers; and charitable business ventures, an income-generation arm of a charity.

Researchers are now publishing in this area, and a body of academic literature is emerging. Young and Lecy consider that social enterprises are organisations or ventures which pursue financial success in the private marketplace in combination with a social purpose. They also argue that social enterprises are more diverse than NFPs and that they are not willing to be confined to one particular sector (Young and Lecy, 2012, p. 3).

\section{The legal definition of 'charity'}

At common law, a 'charity' must be an NFP. ${ }^{8}$ No payment can be made to a charity's members other than for wages or allowances to employees, reimbursement of expenses, or payment for services. This requirement also means that on a winding up, any excess funds must be transferred to an entity with similar purposes.

Prior to the introduction of a statutory definition of 'charity' and 'charitable purpose' in Australia, the Australian courts recognised a legal definition as developed through the common law. ${ }^{9}$ This common law dates back to the Preamble to the 1601 Statute of Charitable Uses, ${ }^{10}$ which listed a range of charitable purposes that included relief of poverty, assistance to scholars and orphans, help to returned soldiers, and repairs to highways and churches.

Subsequently, the House of Lords accepted the guidelines suggested by Lord Macnaghten in Commissioners for Special Purposes of Income Tax $v$ Pemse $^{11}$ in applying the spirit and intendment of the Preamble in a tax scenario. Lord Macnaghten suggested that charitable purposes fall within four divisions. These are the relief of poverty, advancement of education, advancement of religion, and other purposes beneficial to the community not falling under any of the preceding heads. ${ }^{12}$ The classification of charitable purpose into these four areas has been consistently used as a guideline in Australian judicial considerations. ${ }^{13}$ Furthermore, as well as requiring a charitable purpose, entities that aim to qualify as charities must also be of public benefit. ${ }^{14}$

In 2013, Australia followed several other countries and enacted a statutory definition of charity. ${ }^{15}$ The Charities Act 2013 (Cth) (Charities Act) was enacted in 2013 and came into force on 1 January 2014. This legislation includes a definition of charity and charitable purpose. Under the Charities Act, an entity is 'charitable' for federal law purposes if it is a 'charity' within this term as defined in the legislation. ${ }^{16}$ The Act requires that the organisation satisfy four requirements. First, it must be NFP; second, all the entity's purposes must be charitable and for the public benefit (or ancillary or incidental to and in furtherance or in aid of such purposes); third, none of the entity's purposes can be disqualifying purposes; and finally, the entity cannot be an individual, political party, or government entity. ${ }^{17}$

Charitable purposes are defined in s 12(1)(a)-(l) and expanded upon in ss 14, 15, 16, and 17 of the Charities Act. These purposes include the traditional categories of relief of poverty, advancement of education, and religion, ${ }^{18}$ together with others such as promoting reconciliation and protection of the natural environment. Section 12(1)(l) of the Charities Act states that a charitable purpose includes the purpose of promoting or opposing a change to any matter established by law, policy, or practice in the Commonwealth, a State, a Territory, or another country, but the promotion or opposition to change must be in furtherance or in aid of one or more of the purposes set out in s 12(1)(a)-(k).

The public benefit requirement has two overlapping aspects. The purpose or object of the NFP must be 'beneficial' in itself, and it must be of benefit to the community or a sufficient section of the community (with the exception of entities for the relief of poverty, where a more relaxed test is followed). The case law establishes that for the first three heads of charitable 
purposes, 'the court will assume it to be for the benefit of the community and, therefore charitable, unless the contrary is shown'. ${ }^{19}$ It is usually where the charitable purpose falls within the general heading under the common law 'other purposes beneficial to the community' that argument surrounding charitable benefit in this sense arises.

As stated previously, the first aspect of public benefit is that the charity's objectives must provide some actual public benefit. This benefit can, however, extend beyond material benefit to other forms including social, mental, and spiritual. An example of where the courts in Australia have found that a purpose was beneficial was the 1971 decision of The Incorporated Council of Law Reporting of the State of Queensland $v$ The Commissioner of Taxation.$^{20}$ In this case, the High Court of Australia, Australia's highest judicial authority, held that the production of law reports was a matter that was beneficial to the community in a charitable sense.

The public benefit test also requires that the public or a section of the public be benefitted by the charity's objectives. In other words, it cannot be a charity that merely assists a family group or a group of employees. The public benefit test, however, does not mean that the entire public must be benefitted. The case law has accepted that a benefit to a 'sufficient section of the public' is sufficient..$^{21}$ The rationale is that not all charities are for the benefit of the entire community; after all, charities are often motivated by the need to assist a section of the community with special needs or disadvantages. The Chief Justice of the High Court of Australia in 1959, Dixon CJ, expressed it clearly in Thompson v Federal Commissioner of Taxation when his Honour said that the public benefit test can be determined 'by reference to locality, to conditions of people, to their disabilities, defects or misfortunes and by reference to many other attributes of men and things, yet the trusts may retain their "public" character'. ${ }^{22}$

The requirement that a charity must be of public benefit commonly arises in the context of tax concessions. The concern is that private individuals might take advantage of the favourable tax position available to charities for what is essentially a private purpose. ${ }^{23}$ The tax advantages of charities was a strong consideration for Lord Greene in Re Compton when deciding whether a trust for the education of descendants of a named person was a family trust and not charitable because it was not for the benefit of the community. His Lordship came to this conclusion even though the advancement of education is a recognised charitable purpose. ${ }^{24}$

The public benefit test is not applied with the same degree of strictness by courts where the charitable purpose is the relief of poverty. In Re Scarisbricks Will Trust ${ }^{25}$ the Court approved a charity for the relief of poor relatives ('the relations of my son and daughter'). Further, in Dingle $v$ Turner, ${ }^{26}$ the House of Lords granted charitable status to a trust for the relief of poor employees, even though this group was defined through their employment relationship. This approach has been accepted in many cases in England ${ }^{27}$ and Australia. ${ }^{28}$ The rationale seems to be that relief of poverty is overwhelmingly charitable and beneficial to the community.

\section{Can charities carry on businesses?}

In 2008, the common law of Australia confirmed that a charity that engaged in carrying on a business could still maintain its charitable status. This confirmation is found in the High Court decision of Federal Commission of Taxation $v$ Word Investments Limited. ${ }^{29}$ Word Investments Limited was established as a company limited by guarantee in 1975 by members of the Wycliffe Bible Translators Australia. Wycliffe engaged in Christian evangelical purposes and was recognised by the Australian Taxation Office as a charity for the advancement of religion. The memorandum of association of Word Investments allowed it to carry on business activities in connection with its other purposes (which were all clearly charitable as being for the advancement of religion). Any funds from these activities were to go directly to Wycliffe and 
other entities to support the evangelical work and therefore the religious charitable purpose. Word engaged in the business activity of running a funeral business along commercial lines and distributed all surpluses towards its charitable purposes.

The crucial issue was whether an entity could still be considered charitable when it had the capacity to carry on a business, the funds from which would go towards its purposes, which were all charitable. The funeral business was conducted along commercial lines and was open to the general public. The majority in the High Court emphasised that Word's powers to carry on business activities were a means to Word achieving its religious charitable purposes and therefore did not preclude its charitable status. The rationale of the court was:

Word endeavoured to make a profit, but only in aid of its charitable purposes. To point to the goal of profit and isolate it as the relevant purpose is to create a false dichotomy between characterisation of an institution as commercial and characterisation of it as charitable. ${ }^{30}$

Therefore, as long as the entity is an NFP and satisfies all the other requirements, in that it has solely charitable purposes and operates for the benefit of the community or a section of the community, it can retain its charitable status and operate a commercial business. The income from this business will be exempt from income tax in the same manner as all other income of the charity.

The Australian situation is very different to many other jurisdictions (OECD, 2020). ${ }^{31}$ For example, the business income of charities in the United States is taxable under what is referred to as the Unrelated Business Income Tax (UBIT). The UBIT, found in ss 511-514 of the Internal Revenue Code, generally imposes income tax at the corporate tax rate on the unrelated business income of certain tax-exempt entities. The business income must arise from a trade or business that is regularly carried on by the charity and is unrelated to its purposes. 'Unrelated trade or business' is defined in s 513 as

any trade or business the conduct of which is not substantially related (aside from the need of such organization for income or funds or the use it makes of the profits derived) to the exercise or performance by such organization of its charitable, educational, or other purpose or function constituting the basis for its exemption.

Certain exempted types of U.S. unrelated passive income, including dividends, interest, loan proceeds, annuities, royalties, rent from real property, capital gains, and certain other types of income such as research income, are not subject to the UBIT. ${ }^{32}$ However, any kind of investment income is subject to UBIT to the extent that it is debt financed. ${ }^{33}$

Examples of how Australian charities commonly carry on business can be seen through such organisations as the St Vincent de Paul Society and Oxfam. The St Vincent de Paul Society operates stores around Australia that sell second-hand clothing, books, toys, and so on that have been donated by the public. This is not only an efficient means of recycling goods and providing them at low cost to low income earners, but all the profits from the shops go right back into the community, funding local programs like soup vans, food hampers, tutoring programs for disadvantaged children, emergency relief, and accommodation. If we consider the criteria that the Legal Models Working Group set out for a social enterprise, the St Vincent de Paul Society has much in common. It is trading for a social purpose, in that it is assisting low income earners in purchasing clothes and other essentials and is recycling existing goods; second, it is achieving financial sustainability: the goods are donated and then on sold at a small profit, and they are reinvesting profit into the social mission of the enterprise. The only ostensible difference between 
this organisation and an NFP social enterprise is that the St Vincent de Paul Society must have charitable purposes to retain its charitable status. In this case, it is for the relief of poverty and advancement of religion.

Until recently, Oxfam ${ }^{34}$ sold 'fair trade' goods manufactured in developing countries both through its stores and online. A decrease in demand and high overheads has meant that this part of the organisation has closed; however, it still supplies fair trade coffee and drinking chocolate to supermarkets, other outlets, and online. This coffee is sourced from communities in developing countries. Oxfam ensures that the producers are paid a fair price, and all the proceeds are reinvested into Oxfam's projects of alleviating world poverty. ${ }^{35}$ Again, there is little difference in this organisation's aims and how it operates as compared to a social enterprise.

\section{The advantages of being a charity}

For a variety of reasons, both historical and political, most developed nations offer a variety of tax concessions for charities and not-for-profits. In England, ${ }^{36}$ the United States, ${ }^{37}$ Hong Kong, ${ }^{38}$ New Zealand, ${ }^{39}$ and Australia, ${ }^{40}$ the income of charities is generally exempt from income tax. Tax concessions to NFPs represent a significant amount of public sector revenue in Australia, the United States, and other nations. In Australia, the Treasury estimates that the tax deductibility of donations to specific eligible NFPs (including some charities) costs the Commonwealth revenue around $\$ 1.3$ billion per year. ${ }^{41}$ In the United States, this amount is estimated to be $\$ 69.1$ billion dollars for the 2016 fiscal year. ${ }^{42}$

However, just because an organisation is an NFP does not mean that it is eligible for exemption from income tax. An NFP organisation will only be exempt from income tax if it falls into a category of exempt entity. Section 50-5 ITAA97 lists the categories of entities that are exempt from income tax. These entities fall into specific 'main' categories (each category has sub-categories), and this includes charities (ITAA97 s 50-5).

An organisation that is NFP and a charity will therefore be exempt from income tax. Such an organisation is also able to access other Commonwealth tax concessions under the Fringe Benefits Tax ${ }^{43}$ and Goods and Services Tax (GST). ${ }^{44}$ In Australia, charities are also able to obtain a range of tax concessions under state and local government legislation. ${ }^{45}$

\section{Tax deductibility of donations to eligible charities}

Section 30-15 ITAA97 provides that a donation of $\$ 2$ or more to what is referred to as a Deductible Gift Recipient (DGR) is deductible from a taxpayer's assessable income whether the donor is a company or an individual. If the donation is property, then the property must be valued at greater than $\$ 5,000 .{ }^{46}$ If the donation is jointly owned property, the owners work out the share based on each owner's interest in the property. ${ }^{47}$

Australia is unlike the United States and other countries in that it does not place a percentage cap on the deduction for donations. The Australian federal government has instead protected the revenue by limiting the types of organisations that are eligible for donation status. In other words, just because an entity is a charity does not mean that it is a DGR.

The ITAA97 sets out how to determine whether an entity is eligible to be endorsed as a DGR. ${ }^{48}$ The number of DGR categories is more than 40 , which provides insight into the complexity of the system. To be eligible for endorsement under one of what are referred to in the legislation as the general categories, the organisation must fall within a category specified in the ITAA97 and itemised in subdivision 30-B. These general categories are Health, Education, Research, Welfare and Rights, Defence, Environment, The Family, International Affairs, Sports 
and Recreation, Cultural Organisations, Fire and Emergency Services, and Ancillary funds. Examples of the types of entities that are included under the general headings include Public Benevolent Institutions (PBIs), public hospitals, health promotion charities, school building funds (both government and NFP), and necessitous circumstance funds.

The largest group of charities that are eligible for DGR status are PBIs (Cortis et al., 2015, pp. 49-50). The PBI was developed by the legislature to ensure that the tax concession of deductibility of donations was not available to all charities. There are several explanations for this, although currently the paramount one seems to be the protection of the revenue as the donation tax concession is estimated by Treasury to cost the Federal revenue approximately $\$ 1.3 \mathrm{~b}$ per year. ${ }^{49}$ Further reasons that flow from some of the Parliamentary debates and judicial statements at the time the term was inserted in the legislation suggest that the phrase PBI was developed to capture those entities more closely aligned to the traditional view that charities are for the relief of poverty (Martin, 2017) and therefore are the NFPs that should have most significant tax concession privileges (Martin, 2017; Chesterman, 1999, pp. 340-341).

It is the responsibility of the Commissioner of Taxation, the head of the Australian Taxation Office to ensure that the administration of the general categories of DGRs is applied impartially. Furthermore, since 2013, regulation and registration of charities has been vested in the Australian Charities and Not-for-profit Commission (ACNC).$^{50}$ NFPs must register with the ACNC before they can be endorsed by the ATO as charities, ${ }^{51}$ and for charities that wish to become DGRs, this registration is an essential pre-requisite. ${ }^{52}$ Charities therefore face the administrative burden of making separate and different applications to two different government agencies.

Section 30-120 of the ITAA97 provides that the Commissioner may use his endorsement powers according to Division 426 in Schedule 1 to the Taxation Administration Act 1953 to endorse DGRs. The endorsement may be for an organisation or for the operation of a fund, authority, or institution. This means the Commissioner can endorse the organisation or fund itself or endorse the legal person that operates the organisation or fund. Section 30-125 ITAA97 lists the requirements for application for endorsement. The ATO also publishes guides for the NFP sector. These include a Gift Pack to help NFPs to apply for DGR status.

If the organisation or fund does not meet the requirements for the general categories, it may apply for a ministerial decision to change the ITAA97 to specifically list it in the legislation as a DGR. To commence this process, the organisation must write to the Treasurer (ATO, 2013). DGRs listed by name include organisations such as the National Trust and the Australian Sports Foundation. The federal government announced that from 1 July 2019, DGRs that are not government entities will be automatically registered with the ACNC (O’Dwyer, 2017). There is no detail in the media announcement about how this process will occur.

\section{Other benefits of being a charity}

A charitable or a not-for-profit social enterprise may access a range of grants specifically available to promote the mission of those enterprises. However, once the social enterprise becomes a for-profit business, these grants will no longer be accessible to them even though the social enterprise's social mission remains in place (Justice Connect, 2014, p. 15).

\section{The limitations of being a charity}

As discussed earlier, charities must have a charitable purpose as established under the Charities Act. A social enterprise with a mission that does not fall within one of these purposes would therefore not qualify. However, a potentially more significant limitation is that charities cannot access investment 
funds or provide a return to investors from their profits. This is because they must be NFP structures. If a social enterprise is run through a proprietary limited for-profit company, it can issue shares to investors, who can then anticipate a return on their investment and have some say in the management of the company. Chuffed, which is one of the case studies discussed later in this chapter, is a good example of where a charity transitioned to a for-profit model for just these reasons.

\section{Blending social enterprises and charities: three case studies}

Some organisations have managed to work around the previous issues and limitations by either carrying on business through a charity or forming hybrid structures or joint ventures with reputable charities. In this part, I discuss three case studies. Each case study demonstrates a different way of carrying on a social enterprise. The first is a charity, the second a for-profit entity, and the third a hybrid of charity and for-profit structures. I have chosen each situation as a case study for the following reasons. First, each has been written about, and therefore there is publicly available documentation regarding their effectiveness, longevity, or otherwise. Second, each either uses a charity or has used a charity in the past to carry on its social enterprise. Third, each represents a very different way of approaching the carrying on of a social enterprise.

The first case study is Vanguard Laundry Services, a hospital laundry service that provides employment for people suffering from mental illness. The following is a description of this entity:

Vanguard Laundry Services is a social enterprise commercial laundry service based in Toowoomba, Queensland, which provides jobs and employment pathways for people with a lived experience of mental illness who have a history of unemployment. In 2019, the third year of business, Vanguard grew rapidly and increased laundry revenues. While it did not make an operating profit in FY2019, this was achieved early in 2020 .

(Vanguard Laundry Services, 2019, p. 2)

Vanguard operates as a PBI, so it is a charity and DGR, and it partners with several organisations, both charities, businesses, and government, to access operating funds (Vanguard Laundry Services). It operates a commercially successful business, which it can, due to the Word Investments decision. As a charity, it has the advantages of tax concessions, including income tax exemption. As a PBI, donations to it are tax deductible. As discussed in Section III, being a PBI allows it to gain DGR status, and therefore any donations from the public are tax deductible. This is a major incentive to members of the public to make donations. Being a charity does mean that its social mission is limited to charitable purposes. In this case, the social mission of Vanguard Laundry Services fits squarely within charitable purposes to assist the disadvantaged. The other major limitation of operating through a charity is that Vanguard has limited access to investment funds; however, by partnering with business and government, it has managed to obtain funds without losing its charitable status. This is through both donations and grants. In addition, it is making a profit from the business undertaking.

My second case study found the charity structure too confining and moved to a wholly for-profit social enterprise. This organisation is Chuffed. Chuffed.org was established in 2013, and its stated mission was to transform and improve the nature of non-profit fundraising. The organisation was first registered as a company limited by guarantee, and it was a charity. However, the desire to grow the business and attract venture capital while at the same time maintaining its social mission resulted in this organisation transforming from an NFP entity to a hybrid for-profit business which is incorporated as a proprietary company (Paramanathan, 2016). In 
this way, it could raise capital through issuing shares and retain its social mission by embedding this in its constitution.

Chuffed assists in fundraising for projects that have a social, community, or political cause, and promoters can include charities and NFPs (Chuffed, 2018). Chuffed charges fees and also operates courses that are fee paying. Chuffed is clearly carrying on a business, and all proceeds of the business will be assessable income. Some of the ventures that Chuffed engages with would clearly fit within charitable purposes, for example, its many projects raising funds to assist refugees and asylum seekers; however, others, such as 'Ophelia's broken tail' (Ophelia's Broken Tail, 2020), are targeted to assist individuals (in this case a rescued greyhound) and therefore unlikely to fit within a charitable purpose or the public benefit (being targeted at a particular animal and its owners). Chuffed is therefore free from restrictions regarding its social mission and can more easily gain investment funding than a charity; however, it is not income tax exempt, and amounts paid to it are not eligible for a tax deduction. Another advantage is that operating through a proprietary limited company means it has fewer restrictions and reporting requirements than a charity (Nehme and Martin, 2019).

The third case study is a social enterprise that forms a corporate group grouping a DGR with a proprietary company. An example of this corporate group structure may be found in the STREAT organisations.

STREAT Ltd is a Melbourne-based NFP social enterprise that originally operated café businesses that employed young homeless Australians. In 2012, STREAT Ltd bought two cafes and a coffee roasting business from another social enterprise. To protect itself from liability, it created a corporate group that resulted in a hybrid model being created and in which a proprietary limited company would operate the businesses (e.g., Diagram) (Justice Connect, 2014, pp. 14-15).

Diagram of Hybrid structure of STREAT

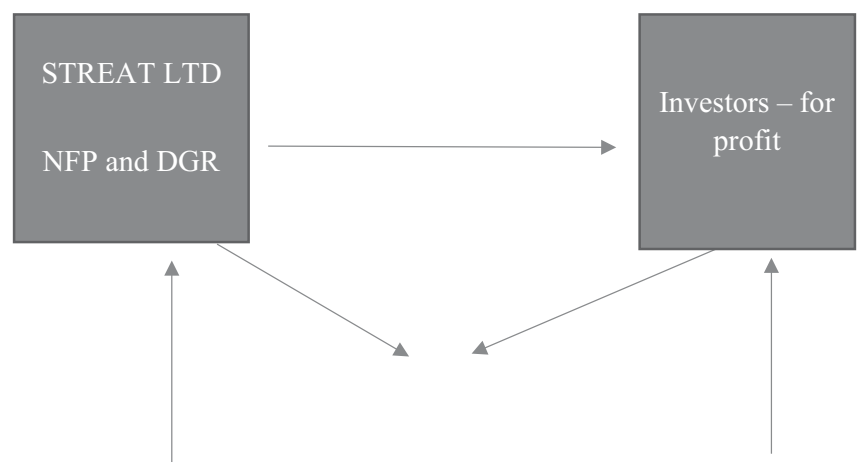

STREAT and Investors own shares in STREAT Enterprises Pty Ltd

STREAT Enterprises pays profits to STREAT and Investors in the form of dividends

\section{STREAT Enterprises Pty Ltd}

Coffee Shops 
STREAT is exempt on all the income that it receives from STREAT Enterprises Pty Ltd. This will be in the form of dividends and, if franked (tax credit on the dividend), STREAT is entitled to a refund of the franking credits. The investors will receive taxable dividends. But, if franked, can access a franking credit. As it is a charity and a DGR, STREAT can access grants and tax-deductible donations. By having a separate entity own the coffee shops, STREAT and the investors are protected from liability if the enterprise is unsuccessful. STREAT Enterprises can also raise funds through issuing shares.

However, it is important to note that running such a structure can be expensive, as there will be a range of legal obligations that need to be complied with, for example, to gain DGR status, the organisation must comply with legal rules that are set out in div 30 ITAA97 and be endorsed by the Australian Taxation Office. Charities are subject to regulation by the ACNC. This cost may stop newly incorporated social enterprises from adopting this model. However, it may be a realistic option once the social enterprise becomes successful.

Clearly, all these entities have the characteristics of social enterprises as established in the FASES Report (Barraket, Mason and Blain, 2016, p. 3). They are led by an economic, social, cultural, or environmental mission consistent with a public or community benefit. In the case of Vanguard, this is to provide employment opportunities for people with mental health issues, which will in turn keep them out of poverty. Chuffed is a crowdfunding platform that raises funds for projects that have a social, community, or political cause. In the case of STREAT, it is homeless youths who are being assisted to gain employment, which will ultimately result in their being able to find affordable housing and lift them out of poverty. All these organisations trade to fulfil their mission, derive a substantial portion of their income from trade, and reinvest most of their profit/surplus in the fulfilment of their mission (Barraket et al., 2010, p. 16).

It appears that there is a spectrum in Australia along which social enterprises may move and develop but that with some developments in their structure, certain opportunities are either lost or gained. At the furthest end of the spectrum is the traditional charity which operates a business that is linked to its charitable purpose, such as a charity shop operated by the St Vincent's de Paul Society. Such an entity must be an NFP, have charitable purposes, and be registered with the ACNC to gain charitable status and therefore income tax exemption. Moving further along the spectrum are also charities, but they operate businesses that are more akin to social enterprises, such as the examples of Vanguard and STREAT. If they are NFPs and have solely charitable purposes, they can maintain charitable status and income tax exemption. If they are also DGRs, donations to them are tax deductible, which is a motivating factor for donations. At the furthest end of the spectrum are social enterprises operating as for-profit businesses. They are liable to income tax; however, they can also access investment funds and pay profits to investors. Somewhere in the middle are hybrid structures such as the STREAT example. However, this requires legal advice and may be costly to establish and maintain.

\section{Conclusion}

This chapter has established that whilst social enterprises and charities can be very different and have very different aims and outcomes, there is also considerable overlap. Many social enterprises have social outcomes that are like charitable purposes. For example, Vanguard Laundry Services describes itself as a social enterprise, but it is also a charity with the charitable purposes of assisting the disadvantaged and alleviating poverty. A social enterprise that puts the environment at the forefront of all decisions and workplace practices would look very similar to a charity for the promotion of the environment. STREAT is a charity and a social enterprise with the aim of educating and assisting the unemployed and thereby ultimately relieving poverty. 
Whilst there is considerable overlap between social enterprises and charities, there are also differences and limitations. Charities have the advantage of being income tax exempt and being able to access grants from both government and charitable organisations. In some cases, they can attract donations that are tax deductible. For-profit social enterprises cannot access these advantages; however, they can access investment from shareholders and, if successful, can provide a return to investors. If a social enterprise operates through a proprietary limited company, it has fewer restrictions and reporting requirements than a charity (Nehme and Martin, 2019).

It is possible in Australia to carry on a business through a charity, and this chapter has provided examples of some charities that have successfully done this. It is also possible that a hybrid structure can be established, as was done by STREAT. However, no one structure will suit all outcomes, and it is important that entrepreneurs take the considerations discussed in this chapter into account before launching a social enterprise.

\section{Notes}

1 Income Tax Act 2007 (UK) ch 3, s 518, ss 524-537. Also, Corporation Tax Act 2010 (UK) c 4 and Taxation of Chargeable Gains Act 1992 (UK) c 12.

2 Inland Revenue Code $\$ 501$ (c) (3) (IRC).

3 Inland Revenue Ordinance (Hong Kong) cap 112, s 88.

4 Income Tax Act 2007 (NZ) CW 41.

5 Income Tax Assessment Act 1997 (Cth) s 50-5 (ITAA97).

6 Charities Act 2013 (Cth) s 5-6.

7 The term not-for-profit is used throughout this chapter as it is generally accepted as the more appropriate term refer I Sheppard, R Fitzgerald and D Gonski, Report into the Inquiry into the Definition of Charities and Related Organisations (2001) 13.

8 Re Smith's Wills Trusts; Barclays' Bank Ltd v Mercantile Bank Ltd [1962] 2 All ER 563; Ann O'Connell, 'The Tax Position of Charities in Australia - Why Does It Have To Be So Complicated?' (2008) 37 Australian Tax Review 17, 24.

9 Salvation Army (Victoria) Property Trust v Shire of Fern Tree Gully (1952) 85 CLR 159.

1043 Eliz. 1, c.4, commonly referred to as the Statute of Elizabeth.

11 [1891] AC 531.

12 [1891] AC 531, 583.

13 See the High Court of Australia in Commissioner of Taxation $v$ Word Investments Limited [2008] HCA 55; Salvation Army (Victoria) Property Trust $v$ Shire of Fern Tree Gully (1952) 85 CLR 159, 173; Ashfield Municipal Council v Joyce (1976) 10 ALR 193; Commissioner of Taxation v The Triton Foundation (2005) 226 ALR 293, 299 (Kenny J).

14 Commissioners for Special Purposes of Income Tax v Pemsel [1891] AC 531; Salvation Army (Victoria) Property Trust $v$ Shire of Fern Tree Gully (1952) 85 CLR 159.

15 For example, in England and Wales, there is now a statutory definition of 'charity' under the Charities Act 2006 (UK).

16 Charities Act, s 5.

17 Charities Act, ss 5-6, 11 and 12.

18 As established by the common law - see Commissioners for Special Purposes of Income Tax v Pemsel [1891] AC 531.

19 National Anti-Vivisection Society v Inland Revenue Commissioners [1948] AC 31, 65.

20 The Incorporated Council of Law Reporting of the State of Queensland $v$ The Commissioner of Taxation (1971) 125 CLR 659.

21 Dingle v Turner [1972] AC 601, 623 (Lord Cross); Oppenheim v Tobacco Securities Trust Co Ltd [1951] AC 297.

22 Thompson v Federal Commissioner of Taxation (1959) 102 CLR 315, 321 (Dixon CJ).

23 Re Compton [1945] Ch 123, 136; Perpetual Trustee Co (Ltd) v Ferguson (1951) 51 SR (NSW) 256, 263 (Sugerman J).

24 Re Compton [1945] Ch 123, 136.

25 Re Scarisbricks Will Trust [1951] 1 Ch 622.

26 Dingle v Turner [1972] AC 601. 
27 See Re Hobourn Aero Components Limited's Air Raid Distress Fund [1946] Ch 194, $203-07$ (Lord Greene MR); Re Scarisbricks Will Trust [1951] 1 Ch 622, 649-52 (Jenkins LJ); Gibson v South American Stores [1950] Ch 177.

28 Alice Springs Town Council v Mpweteyerre Aboriginal Corporation [1997] 139 FLR 236, 252.

29 [2008] HCA 55.

30 [2008] HCA 55, [24].

31 See generally 'Taxation and Philanthropy', OECD Tax Policy Series, November 2020.

32 Internal Revenue Code s 512(b).

33 Internal Revenue Code s 514.

34 Oxfam https://faircoffee.com.au/ (Accessed: 30 September 2020).

35 Oxfam https://faircoffee.com.au/pages/about-us (Accessed: 30 September 2020).

36 Income Tax Act 2007 (UK) ch 3, s 518, ss 524-537. Also, Corporation Tax Act 2010 (UK) c 4 and Taxation of Chargeable Gains Act 1992 (UK) c 12.

37 Inland Revenue Code $\$ 501(c)(3)$ (IRC).

38 Inland Revenue Ordinance (Hong Kong) cap 112, s 88.

39 Income Tax Act 2007 (NZ) CW 41 and CW42.

40 Income Tax Assessment Act 1997 (Cth) s 50-5 (ITAA97).

41 Standing Committee on Tax and Revenue, House of Representatives, Tax Expenditures Statement 2015 (2016), 26-27. No amount is estimated for revenue foregone with respect to the income tax exemption. Tax expenditure is a term used to refer to tax exemptions, deductions; or offsets; concessional tax rates; and deferrals of tax liability.

42 The U.S. Joint Committee on Taxation breaks down the tax expenditures (cost) of charitable deductions into three categories: (1) charitable contribution deductions to educational institutions, $\$ 54.2$ billion; (2) charitable contribution deductions to health organisations $\$ 28.7$ billion; and (3) a catchall category of charitable contribution deductions other than for education and health, $\$ 230.5$ billion: Joint Committee on Taxation, 115th Congress, Estimates of Federal Tax Expenditures for Fiscal Years 2016-2020 (JCX0-3-17), 30 January 2017, 36-38.

43 For example, s 57A Fringe Benefits Tax Act 1986 (Cth) for benefits to employees of health promotion charities and public benevolent institutions (PBIs). PBIs are not-for-profit institutions that are organised for the direct relief of poverty, sickness, and so on and are considered a subset of charities. Refer Taxation Ruling TR 2003/5 'Income Tax and Fringe Benefits Tax: Public Benevolent Institutions' [7], [24]; Gino Dal Pont, Charity Law in Australia and New Zealand (Oxford University Press 2000) 37.

44 For example, charities have a higher GST turnover threshold $(\$ 150,000$ as compared to $\$ 75,000)$ before being required to register for GST, s 23-15 A New Tax System (Goods and Services Tax) Act 1999 (Cth) and certain supplies by charities are GST free under Subdivision 38-G.

45 At the state and local government level, a range of exemptions or concessions in relation to payroll tax, land tax, stamp duty, and local government rates are available to certain charities. For a summary, refer to I. Sheppard, R. Fitzgerald and D. Gonski, Report into the Inquiry into the Definition of Charities and Related Organisations (2001); Commonwealth of Australia Productivity Commission Research Report, Contribution of the Not-for-Profit Sector, (2010), [7.1]; also refer to Fiona Martin, 'Local Government Rates Exemptions for Indigenous Organisations: The Complexities of a State by State System' (2010) 14 Australian Indigenous Law Review 35.

46 ITAA97 s 30-15. Unless it is specific types of shares; see ITAA97 s30-15 items 7, 8.

47 ITAA97 s 30-225.

48 ITAA97 s 30-15.

49 Standing Committee on Tax and Revenue, House of Representatives, Tax Expenditures Statement 2015 (2016), 26-27. No amount is estimated for revenue foregone with respect to the income tax exemption.

50 Australian Charities and Not-for-profits Commission Act 2012 (Cth) ss 10-5 to 15-10.

51 ITAA97 ss $50-4750-110$.

52 ITAA97 ss 30-20, 30-25, 30-45, 30-50.

\section{References}

Australian Charities and Not-for-profits Commission, Australian Charities Report 2017, www.acnc.gov. $\mathrm{au} /$ tools/reports/australian-charities-report-2017 (Accessed: 30 September 2020). 
Australian Institute of Company Directors, Social Enterprise: Role of the Board (NFP Director Tools, 2015).

Australian Law Reform Commission, The Future of Law Reform: Suggested Program of Work 2020-25 (December 2019).

Australian Taxation Office Income Tax Guide for Non-Profit Organisations NAT 7967-03. 2007.

Australian Taxation Office 2008-09 Compliance Program www.ato.gov.au/content/downloads/ COR_0015516_CP0809.pdf 61 (Accessed: 30 September 2020).

Australian Taxation Office, DGRs Listed by Name (5 December 2013) www.ato.gov.au/law/view/ document?docid=SAV/GIFTPACK/00001\#H6 (Accessed: 30 September 2020).

Barraket, Jo, Nick Collyer, Matt O'Connor, and Heather Anderson, Finding Australia's Social Enterprise Sector 2010: Final Report (Australian Centre for Philanthropy and Nonprofit Studies, June 2010).

Barraket, Jo, Heather Douglas, Robyn Eversole, Chris Mason, Joanne McNeill, and Bronwen Morgan, 'Classifying social enterprise models in Australia' 13(4) (2017) Social Enterprise Journal 345.

Barraket, Jo, Chris Mason and Blake Blain Finding Australia's Social Enterprise Sector 2016: Final Report (Centre for Social Impact, Swinburne University of Technology, and Social Trader, 2016).

Boris, Elizabeth T. 'The Nonprofit Sector in the United States: Size and Scope' Urban Institute (2012) https://pdfs.semanticscholar.org/presentation/47af/24c3b53ba5554a7bf4086b4d9f06b4ac01de.pdf.

Brakman Reiser, Dana, and Steven A. Dean, Social Enterprise Law (Oxford: Oxford University Press, 2017), 9-10.

Chesterman, Michael, 'Foundations of Charity Law in the New Welfare State' (1999) 62 Modern Law Review 333, 340-341.

Chuffed, Before You Start, Are You Eligible? (2018) https://chuffed.org/how-it-works-crowdfunding/ before-you-start (Accessed: 30 September 2020).

Chuffed, How to Build a Team to Crowdfund $\$ 91,400$ for Asylum Seekers https://chuffed.org/academy/ articles/detail/against-the-odds-how-libby-and-caroline-crowdfunded-91400-for-people-seekingasylum 2020 (Accessed: 30 September 2020).

Chuffed, Our Fees Are the Lowest (2018) https://chuffed.org/fees (Accessed: 30 September 2020).

Chuffed, We Help You Take Action on Issues You Care About (2018) https://chuffed.org/ (Accessed: 30 September 2020).

Cortis, Natasha et al., 'Australian Charities Report 2015' Centre for Social Impact and Social Policy Research Centre, UNSW Australia, 2015.

Justice Connect Not-for-Profit Law, Social Enterprise Guide, 2014.

Koele, Ineke, Alien, International Taxation of Philanthropy (IBFD 2007) 1.

Martin, Fiona, 'The Sociopolitical and Legal History of the Tax Deduction for Donations to Charities in Australia and How the 'Public Benevolent Institution' Developed' (2017) 38 Adelaide Law Review 195.

Nehme, Marina, and Fiona Martin, 'Social Entrepreneurs: An Evaluation of the Pty Ltd Company from a Corporations Law and Taxation Law Perspective' (2019) Australian Law Journal 125.

O’Dwyer, Kelly, 'Reforming Administration of Tax Deductible Gift Recipients' Media Release, 5 December 2017.

OECD, 'Taxation and Philanthropy', OECD Tax Policy Series, November 2020.

Ophelia's Broken Tail https://chuffed.org/project/ophelias-broken-tail 2020 (Accessed: 30 September 2020).

Oxfam https://faircoffee.com.au/ (Accessed: 30 September 2020).

Oxfam https://faircoffee.com.au/pages/about-us (Accessed: 30 September 2020).

Oxfam https://faircoffee.com.au/pages/our-promise (Accessed: 30 September 2020).

Paramanathan, Prashan, 'Introducing the Social Benefit Company - A New Legal Structure for Australian Social Enterprises' Chuffed Blog (January 2016) https://chuffed.org/blog/the-social-benefit-company (Accessed: 30 September 2020).

Powell, Abigail et al., 'Australian Charities Report 2016' (2017) Centre for Social Impact and Social Policy Research Centre, UNSW Australia.

Pro Bono Australia, 'Creating a Thriving Social Enterprise Sector in Australia' (26 February 2014) https:// probonoaustralia.com.au/news/2014/02/creating-a-thriving-social-enterprise-sector-in-australia/ Accessed: 30 September 2020).

Rodgers, Malcolm, Bronwen Morgan, Fiona Martin, Alan Greig, Robyn Donnelly, Joanne McNeil, Andrew Perry, and Stephen Bennet, Legal Models Working Group, Legal Models Working Group Final Report (2015). 


\section{Social enterprise in Australia}

Salamon, Lester M., S. Wojciech Sokolowski, and Regina List, Global Civil Society: An Overview (Baltimore: Centre for Civil Society Studies The Johns Hopkins University, 2003).

Social Enterprise, United Kingdom, 'What Makes a Social Enterprise a Social Enterprise?' (2012) www. socialenterprise.org.uk/wp-content/uploads/2019/05/What_makes_a_social_enterprise_a_social_ enterprise_April_2012.pdf (Accessed: 30 September 2020).

Social Innovation, Entrepreneurship and Enterprise Alliance (SIEE) Social Enterprise: Doing Business Differently for a More Inclusive Society (2014) 5 https://pollinators.org.au/wp-content/ uploads/2013/09/social_manifesto_13.pdf (Accessed: 30 September 2020).

Social Traders, 'About Us' Social Traders (2019a) www.socialtraders.com.au/about-us/about-social-traders/ (Accessed: 30 September 2020).

Social Traders, 'About Social Enterprises' Social Traders (2019b) www.socialtraders.com.au/about-socialenterprise/what-is-a-social-enterprise/social-enterprise-definition/ (Accessed: 30 September 2020).

Social Traders and the Centre for Social Impact Swinburne, 'Finding Australia's Social Enterprise Sector' (FASES) 2016.

The St Vincent de Paul Society www.vinnies.org.au/page/Shops/NSW/ (Accessed: 30 September 2020).

Standing Committee on Tax and Revenue, House of Representatives, Tax Expenditures Statement 2015 (2016), 26-27. No Amount Is Estimated for Revenue Foregone in Respect of the Income Tax Exemption.

State Government of Victoria, 'Social Enterprise' Business Victoria (17 October 2019) www.business.vic. gov.au/setting-up-a-business/business-structure/social-enterprise (Accessed: 30 September 2020).

The US Joint Committee on Taxation Breaks Down the Tax Expenditures (Cost) of Charitable Deductions into Three Categories: (1) Charitable Contribution Deductions to Educational Institutions, $\$ 54.2$ Billion; (2) Charitable Contribution Deductions to Health Organisations \$28.7 Billion; and (3) a Catchall Category of Charitable Contribution Deductions Other Than for Education and Health, \$230.5 Billion: Joint Committee on Taxation, 115th Congress, Estimates of Federal Tax Expenditures for Fiscal Years 2016-2020 (JCX ᄀר0-3-17), 30 January 2017, 36-38.

Vanguard Laundry Services, '2019 Three Years of Business' 2.

Vanguard Laundry Services, Our Partners www.vanguardlaundryservices.com.au/ (Accessed: 30 September 2020).

Vanguard Laundry Services www.vanguardlaundryservices.com.au/ (Accessed: 30 September 2020).

Young, Dennis, and Jesse Lecy, 'Defining the Universe of Social Enterprise: Competing Metaphors' (2012) Voluntas: International Journal of Voluntary and Nonprofit Organizations, 1. 